\title{
УРАХУВАННЯ БАЛАНСУ ІНТЕРЕСІВ КЛЮЧОВИХ СТЕЙКХОЛДЕРІВ ПРИ ФОРМУВАННІ СУЧАСНОГО БІЗНЕС СЕРЕДОВИЩА ЗАКЛАДІВ ВИЩОї ОСВІТИ
}

\author{
Третяк В.П. докт. екон. наук, доцент \\ Чупова Д.Р.
}

Харківський національний університет імені В. Н. Каразіна

Постановка проблеми. В умовах глобалізації інноваційність і розвиток конкурентоспроможності економіки можливо підтримувати лише за наявності якісної системи освіти та високої якості людського капіталу. Сучасній економіці притаманні такі риси як всебічне посилення конкуренції, високий рівень невизначеності та глобалізаційних ризиків. А це означає, що для відтворення в життя своєї суспільної та економічної ролі заклади вищої освіти (далі - 3ВО) повинні спрямовувати діяльність на підготовку фахівців, кваліфікація яких повною мірою відповідає вимогам національного та світового ринків праці, що в майбутньому забезпечить підвищення їх конкурентного статусу. Наразі за Індексом людського розвитку ООН Україна - держава 3 високим рівнем розвитку завдяки масовості та доступності освіти. Однак у глобальних світових рейтингах, таких як Times Higher Education Ranking, QS Rankings та Best Global Universities Rankings ми поступаємося позиціями. До вказаних рейтингів із 289 закладів вищої освіти України потрапили лише шість українських університетів[1]. Очолюють світові рейтинги найкращих закладів вищої освіти такі університети як Гарвардський університет, Оксфордський університет, Массачусетський технологічний інститут, Кембриджський університет, Стенфордський університет та ін., що знаходяться переважно в США та Великобританії. Позиції українських університетів у зазначених глобальних освітніх рейтингах можемо прослідкувати у таблиці 1 (для перших 500 університетів $\epsilon$ власний номер у рейтингу, інші 3ВО включаються до груп).

Таблиия 1

Позиції українських університетів у глобальних освітніх рейтингах (складено автором на основі [2], [3], [4])

\begin{tabular}{|l|c|c|c|}
\hline \multicolumn{1}{|c|}{ Заклади вищої освіти } & $\begin{array}{c}\text { Times Higher } \\
\text { Education Ranking } \\
\text { (2019) }\end{array}$ & $\begin{array}{c}\text { QS Rankings (2019) } \\
\text { (of 1000) }\end{array}$ & $\begin{array}{c}\text { Best Global Universities } \\
\text { Rankings (2018) } \\
\text { (of 1240) }\end{array}$ \\
\hline $\begin{array}{l}\text { Харківський національний } \\
\text { університету ім. В.Н. Каразіна }\end{array}$ & $1001+$ & 481 & - \\
\hline $\begin{array}{l}\text { Київський національний університет ім. } \\
\text { Т.Г.Шевченка }\end{array}$ & $1001+$ & $531-540$ & - \\
\hline $\begin{array}{l}\text { Національний технічний університет } \\
\text { України «Кийвський політехнічний } \\
\text { інститут імені І. Сікорського» }\end{array}$ & $1001+$ & $601-650$ & - \\
\hline $\begin{array}{l}\text { Національний технічний університет } \\
\text { «Харківський політехнічний інститут» }\end{array}$ & - & $701-750$ & - \\
\hline $\begin{array}{l}\text { Львівський національний університет } \\
\text { І. Франка }\end{array}$ & $1001+$ & $751-800$ & - \\
\hline Сумський державний університет & - & $751-800$ & - \\
\hline
\end{tabular}


Аналізуючи дані зображені у таблиці 1 стає очевидною потреба у формуванні сучасної політики діяльності закладів вищої освіти, охоплюючи спектр питань від державного управління всією системою ЗВО України, до створення локального бізнес-клімату в кожному закладі вищої освіти країни.

Направленість закладу вищої освіти на ринок і споживача вимагає від нього поглиблення та вдосконалення якості наданих освітніх послуг, формування привабливого іміджу університету на місцевому, всеукраїнському та світовому просторі, застосування маркетингових заходів для залучення якомога більшої кількості студентів. Окрім цього в сьогоднішніх економічних умовах оцінюючи конкурентоспроможність ЗВО необхідно враховувати як результативність механізмів організаційно-економічного, фінансового, та стратегічного управління, так і ступінь повноцінності ресурсного потенціалу, який демонструє здатність вузу формувати власні цінності та філософію, відображену у діях у майбутньому.

Таким чином, усе вищезазначене може бути досягнуто завдяки управління узгодженням інтересів стейкхолдерів вищих навчальних закладів.

Аналіз останніх досліджень і публікацій. Дослідженням специфіки будування взаємовідносин між закладами вищої освіти та стейкхолдерами займалися як вітчизняні так і іноземні вчені, цьому було присвячено велика кількість наукових праць. Щодо зарубіжних вчених можна виділити К. Сіммс, К. Чаплео[5], Е. Майндардес, Х. Алвеш, М. Рапозо[6], Д. Шюллер, В. Чалупський[7] I. Маріч[8] та ін. Серед українських вчених слід зазначити роботи А. Шарова[9], I. Тимошенкова, О. Нащекіна[10], Н. Сментина, Р. Хусаінова[11], Н. Савицької[12],С. Панчишина, О. Гринькевича[13] та ін.

А. Шаровим була проведена оцінка впливу різних груп стейкхолдерів на вищу освіту в нашій країні в результаті якої він визначив, що цілі стейкхолдерів університету в цілому мають стабільний характер, тому що вони як правило обумовлені будь-якими життєвими, законодавчими або програмними установками тих чи інших фізичних чи юридичних осіб, їх об'єднань. Але в той же час їх поведінка зазвичай має тенденцію бути схильними до актуальних на даний момент цінностей та стимулів більш низького рівня, які безпосередньо впливають на оцінку життєспроможності освітніх будь-яких проектів[9].

Вчені I. Тимошенков та О. Нащекіна вважають, що завдяки ранжируванню стейкхолдерів відповідно до їхної значущості для університету як для організації і розтановці чітких пріоритетів їх інтересів можна зрозуміти та пояснити загальні тенденції розвитку освіти в цілому в країні і в результаті мати змогу визначити причини можливого погіршення якості фундаментальної або професійної підготовки студентів у закладах вищої освіти взагалі[10].

Як вважають Н. Сментина та Р. Хусаінов, беручи до уваги швидкоплинність та високу динаміку сучасного глобального освітнього середовища, підвищення конкуренції та боротьба між різними закладами вищої освіти за ресурси, студентів, абітурієнтів, висококваліфікованих викладачів, вчених, дослідників - усе це безумовно вимагає від закладу вищої освіти дуже інтенсивно взаємодіяти 3 усіма групами наявних стейххолдерів 3 метою 
досягнення позитвиних результатів, поліпшення тієї чи іншої сфери діяльності в ЗВО та підвищення конкурентоспроможності задля отримання більшої долі ринку в боротьбі за ресурси та студентів[11].

Невирішені складові загальної проблеми. Серед проблем сучасного закладу вищої освіти має місце пошук сучасних шляхів взаємодії між ключовими стейкхолдерами ЗВО, особливо це стосується визначення портрету студентів сучасного покоління, їхніх особливостей та відмінностей від попереднього покоління та зацікавлення молоді до навчання.

Формулювання цілей статі. Основною ціллю статті $є$ визначення ключових стейкхолдерів ЗВО, виділення категорії «студент» як однієї 3 найважливіших категорій стейкхолдерів, пошук шляхів ефективної їх взаємодії 3 метою налагоджування та підтримки довгострокових взаємовідносин та виокремлення принципово нових можливостей для формування ефективного бізнес середовища та підвищення конкурентного статусу закладу вищої освіти.

Виклад основного матеріалу дослідження. В сучасних умовах господарювання актуальним стає питання модернізації освіти та формування ефективного бізнес середовища, яке могло б сприяти формуванню тісних взаємовідносин між ЗВО та колами зацікавлених в його розвитку осіб.

Бізнес-середовище в економічній літературі визначається як комплексна, багатофункціональна система. Під бізнес-середовищем зазвичай мають на увазі набір усіх внутрішніх та зовнішніх аспектів функціонування організації, які в той чи інший спосіб мають вплив на ії діяльність. До цих аспектів належать такі категорії постачальники, споживачі, конкуренти, державне регулювання, соціальні, політичні, технологічні, правові та екологічні та інші умови[14]. Тож можемо сказати, що складовими бізнес-середовища $є$ зацікавлені (або не зацікавлені) у розвитку організації суб' єкти, тобто стейкхолдери.

Стейкхолдер - це особа, група осіб або організація, що може впливати, на яку можуть впливати або яка може бути піддана впливу щодо рішення, операції, проекту або результату діяльності організації[15].

Така група стейколдерів як студенти, випускники та їхні батьки мають безпосередній вплив на успіх університету, оскільки вони подаючи документи та навчаючись у тому чи іншому закладі формують масу студентів задля якої існує та функціонує цей заклад.

Наступна група стейколдерів - підприємства, організації (в т.ч. суспільні союзи), міжнародні установи та організації виступають у взаємодії з ЗВО споживачами продукту вузу, наймаючи на роботу студентів випускників, споживачами освітніх послуг для свого персоналу або ж споживачами консалтингових послуг i науково-технічних розробок, які ЗВО може надати комерційним організаціям. Сутність взаємодії ЗВО 3 представниками ЗМІ зазвичай полягає у тому, що завдяки засобам масової інформації сьогодні будьяку подію чи досягнення можна висвітлити для великої аудиторії дуже швидко та ефективно. Тож ЗМІ також $\epsilon$ частими споживачами послуг, які надає університет. Щодо інших навчальних закладів (вітчизняних та зарубіжних) вони можуть виступати як партнерами для обміну інформацією та досвідом, 
приймати участь у спільній науковій діяльності, здійснювати підвищення кваліфікації за рахунок одне одного, так і виступати конкурентами та «приводом» зростати швидше, ніж інші. Громадські організації зазвичай виступають своєрідною платформою для діяльності вузів, дозволяючи їм проводити різноманітті дослідження, видавати ліцензії, гранти, проводити атестації. Взаємодія вузів з центральними та місцевими органами державної влади, Міністерством освіти України полягає у плануванні, фінансуванні, систематизації діяльності ЗВО, виробленні освітніх стандартів та норм, завдяки яким може існувати університет. Керівництво ЗВО, адміністративний персонал, науково-педагогічний персонал та інші робітники закладів учасниками, які безпосередньо займаються передаванням знань та умінь від викладача до студента, формують наукові надбання та імідж ЗВО.

Перейдемо безпосередньо до виокремлення категорій стейкхолдерів 3 якими взаємодіє заклад вищої освіти, що допоможе нам більш детально розглянути питання формування бізнес середовища в ЗВО (схема зображена на рисунку 1).

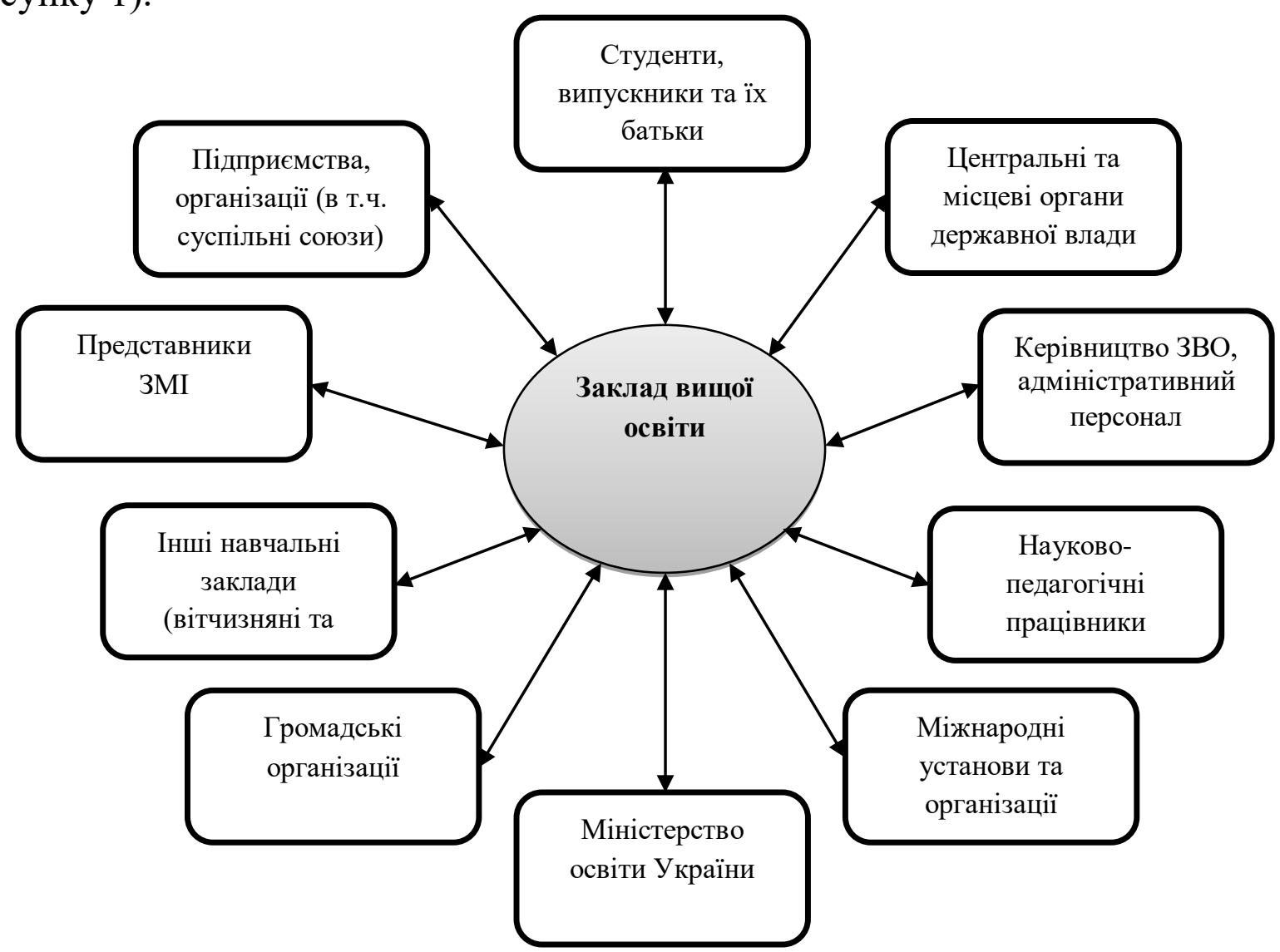

Рис. 1. Категорії стейкхолдерів, з якими взаємодіс заклад вищої освіти (розробка автора)

Наведена схема показує, що ЗВО має достатньо велику кількість тих суб'єктів, які можуть бути зацікавлені у взаємодії та співпраці.

Тож ми визначили, що для розробки методів взаємодії стейкхолдерів необхідно поглиблене вивчення специфіки кожної з категорій. В даній статті ми зосередимося на дослідженні однієї з ключових груп стейкхолдерів - студенти та науково-педагогічні працівники. 
Сьогодні у процесі роботи зі студентами викладачі часто зазначають, що студенти попередніх років та сучасні студенти багато в чому відрізняються у своїх потребах, у мотивації до навчання, у базових знаннях та навичках, шляхах концентрації уваги, взаємодії з іншими студентами, викладачами, тощо.

Тож студенти, що народилися у різні часи мать зазвичай зовсім різні цілі та розвиваються, навчаються та дорослішають у різних умовах. Цих студентів доцільно відносити до різних поколінь.

Такі особливості найкраще описує теорія поколінь, яка була розроблена Вільямом Штраусом і Нілом Хоувом у 1991 році й описує цикли поколінь у США та в інших країнах світу. Теорія поколінь графічно зображена на рисунку 2.

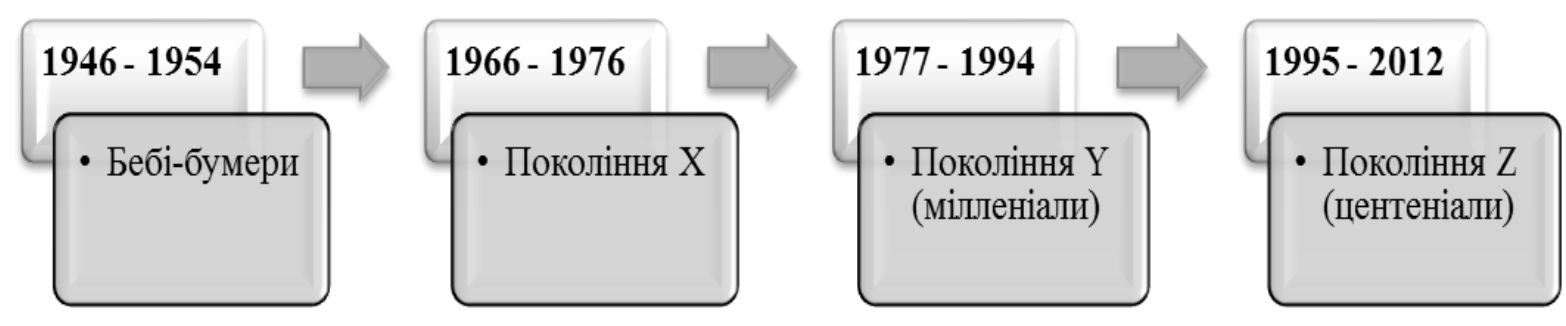

Рис. 2. Теорія поколінь, розроблена Вільямом Штраусом і Нілом Хоувом (складено автором на основі [16])

Покоління - це набір людей, які народжуються в певний період часу. Найбільш активними та поширеними типами поколінь у сучасному світі $є$ :

- Бебі-бумери - народжені у 1946-1954. Оптимізм, зацікавленість в особистісному рості, але в той же час в побудові колективу.

- Покоління X - народжені у 1966-1976. Готовність до змін, прагнення вчитися протягом усього життя, пошук емоцій, прагматизм, надія на себе.

- Покоління Y - мілленіали, народжені у 1977-1994. Громадянський обов'язок i мораль, відповідальність, але при цьому наївність і вміння підкорятися.

- Покоління Z - центеніали, народжені в 1995-2012. С першим повністю цифровим поколінням, характерна нетерплячість, егоцентричність, несхильність до субординації, рівноправ'я, толерантність[16].

Покоління $\mathrm{Z}$ - це люди, які народилися в епоху Інтернету, а значить і не уявляють свого життя без нього. Також для них характерні комунікації не в реальному житті, а за допомогою соціальних мереж, їм значно комфортніше замінити будь-яку зустріч чи телефонний дзвінок текстовим повідомленням. В них не має розділення світу на віртуальний, тобто цифровий та реальний, тому що люди народжені у цей період вважають це одним єдиним світом.

Люди Покоління Z з дитинства користуються Інтернетом перебувають в онлайн більшу частину свого часу, знають особливості усіх соціальних мереж та швидко вчяться користуватися будь-якими інноваціями у цій сфері.

Центеніали схильні більше сприймати інформацію картинками та схемами, ніж читати звичайний довгий текст, вони звикли до великої кількості 
реклами в мережі Інтернет, тому не звертають на неї увагу, а тому щоб зацікавити їх потрібно докласти неабияких зусиль, так як це покоління вже «перенасичено» різноманітною інформацією.

Останніми роками саме покоління студентів $\mathrm{Z}$ або центеніалів розпочало отримувати вищу освіту, тому майже всі бакалаври, які навчаються у данний момент у вищих навчальних закладах є студентами Z. Тож розглянемо більш детально «портрет» сучасного студента Z, його характерні особливості:

Навчаються по-своєму. Люди покоління Z зазвичай не вивчають лише один певний предмет, їм зручніше комбінувати та узагальнювати, усвоюючи декілька споріднених предметів в один і той же час.

Нетерплячі. Центеніали виросли в онлайн-середовищі та часто вважають, що в житті все будь-яке бажання або ідею можна реалізувати так само швидко, як і в віртуальному світі.

Самостійні. Центеніали вважають, що в 21 сторіччі викладач не $є$ основним джерелом одержання компетенції в будь-якій сфері, тому що можна миттєво знайти потрібну інформацію в Інтернеті, тож роль викладача змінилася на своєрідного провідника та людини, яка може проаналізувати великі об'єми інформації та навчити самому основному та потрібному.

Залежні від Інтернету та не уявляють свого життя без нього. Більшу частину свого дня знаходяться онлайн у різноманітних соціальних сітях, грають у онлайн ігри, діляться своїм життям у блогах та ін.

Стрімко перемикають увагу. Студентам покоління Z часто важко зосередитися на одній задачі, вони не можуть довго працювати над монотонною роботою. Цьому поколінню притаманна гіперактивність, вони не схильні повертатися до однієї задачі декілька разів, тому одразу приймають швидкі та остаточні рішення.

Толерантні. Люди $Z$ виховані у сучасному світі, вони знають його різноманітність, а тому серед них немає місця дискримінації за расовими, національними чи гендерними причинами.

Цінують безпеку. Як в Інтернеті, так i в реальному житті. Усвідомлюють, що таке теракти, катастрофи, кризи та мають бажання зробити все, щоб попередити усі можливі негативні ситуації.

Мінімалісти. Обирають скоріше одну якісну дорогу річь, замість декількох неякісних, але дешевших, вільно позбавляються зайвих речей, віддають перевагу шопінгу онлайн, частіше використовуючи при цьому мобільний телефон, аніж комп’ютер, тому що це зручніше та швидше

Швидко стають дорослими. Студенти цього покоління ростуть в епоху жорсткої конкуренції, в якій щоб залишатися конкурентоспроможним на ринку фахівців, потрібно якомога раніше починати працювати в тій сфері, в якій вони хочуть стати успішними. Велика кількість 3 них займаються розробкою власних стартапів та мріють бути підприємцями.

Ведуть здоровий спосіб життя. Центеніали як правило практично не уживають алкогольних напоїв та не мають поганих звичок, у їх поколінні модно уважно ставитися до свого здоров'я та займатися спортом. 
Отже, підсумувавши та проаналізувавши типовий «портрет» сучасного студента Z, можемо сказати, що ці студенти володіють нестандартним та прогресивним набором рис, а отже у розробці підходів до взаємодії зі студентами цього покоління необхідно додержуватися креативності, інноваційності та мобільності. У таблиці 2 зображені основні запропоновані нами способи взаємодії зі студентами покоління $\mathrm{Z}$ та варіанти реалізації цих взаємодій.

Способи взаємодії зі студентами покоління $Z$ та варіанти реалізації цих взаємодій

Таблиия 2 (розробка автора)

\begin{tabular}{|c|c|}
\hline Спосіб взаємодії & Варіанти реалізації \\
\hline Дистанційні курси & $\begin{array}{l}\text { - Класичні дистанційні курси (власні та іниих викладачів, як окремо } \\
\text { - } \quad \text { Вак і частково) } \\
\text { Вебаняття та виконання семінарських завдань онлайн }\end{array}$ \\
\hline Мікро-уроки & $\begin{array}{l}\text { - Надання студентам окремого контенту деталізаиї̈ двох рівнів (де } \\
\text { периий рівень - зміст, а другий - повний конспект лекиї̈ з } \\
\text { додатковими матеріалами) }\end{array}$ \\
\hline $\begin{array}{l}\text { Взаємодія з соціальними } \\
\text { мережами }\end{array}$ & $\begin{array}{l}\text { - Чат дисиипліни } \\
\text { - Чат з кураторами груп студентів } \\
\text { - Утворення сторінок в соціальних мережах (інстаграм, фейсбук) } \\
\text { - Система Mоодle }\end{array}$ \\
\hline Гейміфікація & $\begin{array}{l}\text { - } \quad \text { Імітаиія реальних ситуаиій в ігровій формі на парах } \\
\text { - } \quad \text { Розбір кейсів } \\
\text { - Проведення конкурсів, турнірів, фахових ігор }\end{array}$ \\
\hline Відеоматеріали & $\begin{array}{l}\text { - } \quad \text { Відео на ютубі з лекиіями та наочним матеріалом } \\
\text { - Проведення вебінарів викладачами }\end{array}$ \\
\hline $\begin{array}{l}\text { Персоналізація освітніх } \\
\text { програм }\end{array}$ & $\begin{array}{l}\text { - Дійсна персоналізація (для маленьких груп) } \\
\text { - Шаблонна персоналізація (для великих груп) }\end{array}$ \\
\hline
\end{tabular}

Тож данні таблиці свідчать, що існує велика кількість шляхів та способів реалізації взаємодії зі студентами нового покоління, які можна застосувати викладачам у процесі навчання.

Висновки 3 проведеного дослідження. В процесі дослідження ринку освітніх послуг було визначено ключових стейкхолдерів ЗВО та виділено і проаналізовано таку категорію як «студент» більш детально, у процесі чого було зроблено висновок, що для більш ефективної взаємодії зі студентами покоління Z, необхідно впроваджувати такі способи навчання, які будуть зрозумілі, а головне цікаві студентам, які зараз навчаються в закладах вищої освіти, а саме: заснування дистанційних курсів, розроблених як власними викладачами, так і використання онлайн - курсів найкращих ЗВО світу. Задля розширення спектру вивчення предмету, ці дистанційні курси можуть бути як у вигляді різноманітних лекцій та завдань, так і в вигляді наочного матеріалу 3 супроводженням відео, схем та картинок. Також актуальним сьогодні буде використання мікро-уроків, де студентам надається окремий контент деталізації двох рівнів, де перший рівень - зміст та основна інформація, яка повинна бути засвоєна студентом, а другий - повний конспект лекції 3 додатковими матеріалами у разі необхідності поглиблення знань та навичок. 
Окрім цього на даний час вкрай необхідним є інтегрування в процес освіти соціальних мереж, тому що це основний канал через який можна швидко та ефективно взаємодіяти 3 учнями та отримувати зворотній зв'язок. Інтегрування може проходити шляхом створення чатів 3 викладачами та студентами з приводу різних тем, наприклад чат дисципліни, чат новин, чат 3 кураторами груп; утворення сторінок факультету або кафедри в соціальних мережах (інстаграм, фейсбук) для висвітлення останніх новин або нововведень, можливості залишити відгук студента або запропонувати своє бачення розвитку факультету/кафедри. Використання системи Moodle, де можна пройти весь процес навчання від вивчення лекцій до здачі заліку в режимі онлайн.

Наразі актуальним $є$ також гейміфікація процесу навчання, тобто імітація реальних ситуацій в ігровій формі на парах, розбір кейсів, проведення конкурсів, турнірів, фахових ігор тощо. Використання відеоматеріалів може втілюватися через викладання лекцій або цікавих фахових роликів у соціальні мережі для вільного доступу та перегляду студентами, проведення вебінарів, тобто онлайн семінарів, що проходять в мережі інтернет, де викладач може взаємодіяти зі студентами, як в реальності. Окрім цього наразі актуальним $\epsilon$ персоналізація освітніх програм, тобто створення особистого освітнього профайлу з переліком сильних сторін, мотивацій, цілей студента, особисто розроблений за допомогою викладачів освітній план, набір компетенцій, якими би він хотів оволодіти, тобто комплексний та індивідуальний підхід до кожного - усе це допомагає викладачам взаємодіяти зі студентами більш ефективно та інноваційно і в результаті мати змогу виводити вищу освіту в Україні на якісно новий рівень. Тож урахування балансу інтересів таких ключових стейкхолдерів, як студенти та науково-педагогічні працівники дасть велику кількість нових можливостей для створення високих конкурентних позицій при формуванні бізнес середовища закладів вищої освіти.

\section{Перелік посилань}

1. Економічна Стратегія України 2030, «Україна - learning nation». Украӥнський інститут майбутнього. Режим доступу: https://strategy.uifuture.org/ukraina-learning-nation.html

2. The Times Higher Education World University Rankings 2019. URL: https://www.timeshighereducation.com/world-university-rankings/2019/worldranking\#!/page/0/length/25/sort_by/rank/sort_order/asc/cols/stats

3. QS World University Rankings 2019. QS Top Universities. URL: https://www.topuniversities.com/university-rankings/world-university-rankings/2019

4. Best Global Universities Rankings. US News and World Report Education. URL: https://www.usnews.com/education/best-globaluniversities/rankings

5. Simms C., Chapleo C.. Stakeholder analysis in higher education: acasestudy of the University of Portsmouth. Perspectives. Policy and Practice in Higher Education. 2010. No 14 (1). P. 12-20. 
6. Mainardes E., Alves H., Raposo M. An Exploratory Research on the Stakeholders of a University. Journal of Management and Strategy. 2010. Vol. 1. No 1. P. 66-88. URL: http://dx.doi.org/10.5430/jms.v1n1p76.

7. Schüller D., Chalupský V. Marketing Communication Managemen to Higher Education Institutions. Acta Univ. Bohem. Merid. 2012. No 15(2). P. 61-69.

8. Marić I., Stakeholder analisys of higher education institutions. Interdisciplinary Description of Complex Systems. 2013. No 11(2). P. 217-226. URL: https://hrcak.srce.hr/file/148291

9. Шаров А. I. Побудова інструментарію дослідження життєспроможності освітнього проекту та його можливого мультиплікативного ефекту. Управління проектами та розвиток виробництва. 2012. №2(42). С. $1-9$.

10. Тимошенков I. В., Нащекіна О. М. Суб'єкти, агенти, актори і стейкхолдери в економічних дослідженнях освіти. Вчені зап. Харк. гуманіт. унту «Нар. укр. акад.». Х., 2012. Т. 18, кн. 1 : Освіта: традииї та інновації в умовах соиіальних змін. С. 167-176.

11. Сментина Н. В., Хусаінов Р. В. Соціальна відповідальність вищих навчальних закладів: концептуальний аналіз. Науковии вісник Херсонського державного університету. 2014. No9(2). C. 20-25.

12. Савицька Н. Л. Освіта і господарський розвиток: теоретикометодологічне осмислення базових категорій. Економіка. Управління. Інновації: 2014. No 2. URL: http://nbuv.gov.ua/UJRN/eui_2014_2_52.

13. Панчишин С. М., Гринькевич О. С. Поняттєвий апарат інституційного аналізу конкурентоспроможності системи вищої освіти. Економіка розвитку. 2017. № 1(81). С. 50-58.

14. Буряк Г. Інститути розвитку відносин власності у класифікації бізнес-середовища. Актуальні проблеми міжнародних відносин. 2012. Випуск 105. Ч. II. C. 26-28.

15. Керівництво до Своду знань з управління проектами. Керівництво РМВОК. 5-е вид. Pennsylvania: Project Management Institute, Inc., 2013. 614 c.

16. Strauss W. Generations : The History of America's Future, 1584 to 2069 / William Strauss, Neil Howe. New York : Morrow, 1991. 538 p.

\section{References}

1. Economic Strategy of Ukraine 2030, "Ukraine - learning nation". Ukrainian Institute of the Future [Ekonomichna Stratehiia Ukrainy 2030, «Ukraina learning nation»], available at : https://strategy.uifuture.org/ukraina-learningnation.html

2. The Times Higher Education World University Rankings 2019, available at : https://www.timeshighereducation.com/world-university-rankings/2019/worldranking\#!/page/0/length/25/sort_by/rank/sort_order/asc/cols/stats

3. QS World University Rankings 2019, QS Top Universities, available at : https://www.topuniversities.com/university-rankings/world-university-rankings/2019 
4. Best Global Universities Rankings, US News and World Report Education, available at : https://www.usnews.com/education/best-globaluniversities/rankings

5. Simms, C., Chapleo, C. (2010), Stakeholder analysis in higher education: acasestudy of the University of Portsmouth, Perspectives, Policy and Practice in Higher Education, No 14 (1). P. 12-20.

6. Mainardes, E., Alves, H., Raposo, M. (2010), An Exploratory Research on the Stakeholders of a University, Journal of Management and Strategy, Vol. 1, No 1, P. 66-88, available at : http://dx.doi.org/10.5430/jms.v1n1p76.

7. Schüller, D., Chalupský, V. (2012), Marketing Communication Managemen to Higher Education Institutions, Acta Univ, Bohem, Merid, No 15(2), P. 61-69.

8. Marić, I. (2013), Stakeholder analisys of higher education institutions. Interdisciplinary Description of Complex Systems, No 11(2), P. 217-226, available at : https://hrcak.srce.hr/file/148291

9. Sharov, A. I. (2012), Development of a toolkit for research into the viability of an educational project and its possible multiplier effect [Pobudova instrumentariyu doslidzhennya zhy'ttyespromozhnosti osvitn'ogo proektu ta jogo mozhly'vogo mul'ty'plikaty'vnogo efektu], Project management and production development, No2(42), P. 1-9.

10. Ty'moshenkov, I. V., Nashhekina, O. M. (2012), Subjects, Agents, Actors, and Stakeholders in Economic Studies in Education [Sub'yekty', agenty', aktory' i stejkxoldery' v ekonomichny'x doslidzhennyax osvity', Vcheni zap. Xark. gumanit. un-tu «Nar. ukr. akad.»], Education: traditions and innovations in the face of social change, X., T. 18, kn. 1, P. 167-176.

11. Smenty'na, N. V., Xusainov, R. V. (2014), Social responsibility of higher education institutions: a conceptual analysis [Social'na vidpovidal'nist' vy'shhy'x navchal'ny'x zakladiv: konceptual'ny'j analiz], Scientific Bulletin of Kherson State University, No9(2), P. 20-25.

12. Savy'cz'ka, N. L. (2014), Education and economic development: theoretical and methodological understanding of basic categories [Osvita $i$ gospodars'ky'j rozvy'tok: teorety'ko-metodologichne osmy'slennya bazovy'x kategorij], Economy. Management. Innovation, No 2, available at : http://nbuv.gov.ua/UJRN/eui_2014_2_52.

13. Panchy'shy'n, S. M., Gry'n'kevy'ch, O.S. (2017), Conceptual apparatus of the institutional analysis of the competitiveness of the higher education system. [Ponyattyevy'j aparat insty'tucijnogo analizu konkurentospromozhnosti sy'stemy' vy'shhoyi osvity'], Economics of development, No 1(81), P. 50-58.

14. Buryak, G. (2012), Institutes for the development of property relations in the classification of business environment [Instytuty rozvytku vidnosyn vlasnosti $\mathrm{u}$ klasyfikatsii biznes-seredovyshcha], Topical problems of international relations, Issue 105, Part II, P. 26-28. 
15. Guide to the Project Management Knowledge Code (2013), [Kerivnytstvo do Cvodu znan z upravlinnia proektamy], PMBOK Guide, The 5th species, Pennsylvania: Project Management Institute, Inc., 614 p.

16. Strauss, W. (1991), Generations : The History of America's Future, 1584 to 2069 / William Strauss, Neil Howe, New York : Morrow, 538 p.

\section{РЕФЕРАТИ РЕФЕРАТЫ ABSTRACTS}

\section{УДК 338.46:378:[330.117:330.161]; JEL Classification: I230}

Третяк В.П., ЧУПова Д.Р. УРАХУВАННЯ БАЛАНСУ ІНТЕРЕСІВ КЛЮЧОВИХ СТЕЙКХОЛДЕРІВ ПРИ ФОРМУВАННІ СУЧАСНОГО БІЗНЕС СЕРЕДОВИЩА ЗАКЛАДІВ ВИЩОЇ ОСВІТИ

Мета дослідження полягає в визначенні основних стейкхолдерів у сфері вищої освіти, пошуку шляхів ефективної взаємодії з однією з найважливіших категорій - «студент», з ціллю налагоджування та підтримки довгострокових взаємовідносин для впровадження принципово нових можливостей, що в майбутньому забезпечить формування сучасного бізнес середовища та підвищить конкурентний статус закладу вищої освіти. Методика дослідження. Для досягнення поставленої мети були використані наступні загальнонаукові та спеціальні методи і прийоми дослідження: методи узагальнення та абстрагування - для виявлення сутності взаємозв'язку основних стейкхолдерів на ринку освітніх послуг, виділення категорій стейкхолдерів та описання сутності цих категорій; методи аналізу і синтезу для формування способів взаємодій зі студентами покоління $\mathrm{Z}$ та розробки варіантів реалізації цих взаємодій. Результати дослідження. В процесі дослідження ринку освітніх послуг було виділено ключових стейкхолдерів 3ВО та проаналізовано групи стейкхолдерів - студенти та науково-педагогічні працівники. Було визначено, що для більш ефективної взаємодії зі студентами покоління Z, необхідно впроваджувати такі способи навчання, які будуть зрозумілі, а головне цікаві студентам, а саме: заснування дистанційних курсів, мікро-уроків, взаємодії з соціальними мережами, гейміфікації, відеоматеріалів, персоналізації освітніх програм та ін. Наукова новизна. В результаті дослідження запропоновано схему взаємодії категорій стейкхолдерів 3 закладом вищої освіти. Виявлено взаимозв'язок ключових стейкхолдерів студенти та науково-педагогічні працівники, що дозволило уточнити характеристику сучастного «портрету» студента покоління Z. Запропоновано новітні методи взаємодії зі студентами покоління $\mathrm{Z}$ та варіанти реалізації цих взаємодій. Практична значущість полягає в тому, що методичні підходи, теоретичні висновки та практичні рекомендації можуть бути використані у процесі формування сучасного бізнес середовища закладів вищої освіти, та дозволить ураховувати баланс інтересів ключових стейкхолдерів за рахунок зменшення розривів в їх інтересах. 
Ключові слова: стейкхолдери; бізнес середовище; заклад вищої освіти; студенти; науково-педагогічні працівники; студенти покоління Z; шляхи навчання центеніалів.

\section{УДК 338.46:378:[330.117:330.161]; JEL Classification: I230}

\section{Третяк В.П., Чупова Д.Р. УЧЕТ БАЛАНСА ИНТЕРЕСОВ}

\section{КЛЮЧЕВЫХ СТЕЙКХОЛДЕРОВ ПРИ ФОРМИРОВАНИИ СОВРЕМЕННОЙ БИЗНЕС СРЕДЫ УЧРЕЖДЕНИЙ ВЫСШЕГО ОБРАЗОВАНИЯ}

Цель исследования заключается в определении основных стейкхолдеров в сфере высшего образования, поиска путей эффективного взаимодействия с одной из важнейших категорий - «студент», с целью налаживания и поддержания долгосрочных взаимоотношений для внедрения принципиально новых возможностей, которые в будущем обеспечат формирование современной бизнес среды и повысят конкурентный статус учреждения высшего образования. Методика исследования. Для достижения поставленной цели были использованы следующие общенаучные и специальные методы и приемы исследования: методы обобщения и абстрагирования - для выявления сущности взаимосвязи основных стейкхолдеров на рынке образовательных услуг, выделение категорий стейкхолдеров и описание сущности этих категорий; методы анализа и синтеза - для формирования способов взаимодействия со студентами поколения $\mathrm{Z}$ и разработки вариантов реализации этих взаимодействий. Результаты исследования. В процессе исследования рынка образовательных услуг было выделено ключевых стейкхолдеров УВО и проанализированы группы стейкхолдеров - студенты и научно-педагогические работники. Было определено, что для более эффективного взаимодействия со студентами поколения Z, необходимо внедрять такие способы обучения, которые будут понятны, а главное интересные студентам, а именно: использование дистанционных курсов, микро-уроков, взаимодействие с социальными сетями, геймификация, видеоматериалы, персонализация образовательных программ и др. Научная новизна. В результате исследования предложена схема взаимодействия категорий стейкхолдеров с заведением высшего образования. Выявлено взаимосвязь ключевых стейкхолдеров студентов и научно-педагогических работников, что позволило уточнить характеристику современного «портрета» студента поколения Z. Предложено новейшие методы взаимодействия со студентами поколения $\mathrm{Z}$ и варианты реализации этих взаимодействий. Практическая значимость заключается в том, что методические подходы, теоретические выводы и практические рекомендации могут быть использованы в процессе формирования современной бизнес среды высших учебных заведений, и позволит учитывать баланс интересов ключевых стейкхолдеров за счет уменьшения разрывов в их интересах. 
Ключевые слова: стейкхолдеры; бизнес среда; учреждение высшего образования; студенты; научно-педагогические работники; студенты поколения $\mathrm{Z}$; пути обучения центениалов.

\section{UDC 338.46:378:[330.117:330.161]; JEL Classification: I230}

$\begin{array}{llllllll}\text { Tretyak V. P., Chupova D. R. THE BALANCE OF KEY } & \text { D. }\end{array}$ STAKEHOLDERS' INTERESTS IN THE FORMATION OF MODERN BUSINESS ENVIRONMENT IN HIGHER EDUCATION INSTITUTIONS

The purpose of the study is to identify major stakeholders in higher education, to find ways of effective interaction with one of the most important categories "student", with the aim of establishing and maintaining long-term relationships for the introduction of fundamentally new opportunities, which in the future will create modern business environment and increase a competitive status status of a higher education institution. Methodology of research. The following general scientific and specific research methods and techniques were used: generalization and abstraction methods in order to identify the essence of the main stakeholders in the educational services market, to identify categories of stakeholders and to describe the essence of these categories; analysis and synthesis methods in order to form the ways of interaction with students of generation $\mathrm{Z}$ and develop of variants of realization of these interactions. Findings. During the study of the market for educational services, key stakeholders of the University were identified and groups of stakeholders, students and research staff, were analyzed. It has been determined that in order to interact more effectively with students of Generation Z, it is necessary to introduce such learning methods that will be understood and, above all, will interest students, namely: the establishment of distance courses, micro-lessons, interaction with social networks, gamification, video materials, personalization of educational programs and others. Originality. As a result of the research, a scheme of interaction of categories of stakeholders with higher education institution was proposed. The interrelation between key stakeholders - students and teaching staff - was revealed, which made it possible to clarify the characterization of a contemporary portrait of a student of generation Z. Practical value is that methodological approaches, theoretical conclusions and practical recommendations can be used in the process of forming modern business environment of higher education institutions, and they will allow to balance the interests of key stakeholders by reducing the gaps in their interests.

Key words: stakeholders; business environment; higher education institution; students; teaching staff; students of Generation Z; ways of learning centennials. 


\section{Відомості про авторів / Сведения об авторах / About the Authors}

Третяк Вікторія Павлівна - доктор економічних наук, доцент, ННI «Каразінська школа бізнесу», завідувач кафедри управління та адміністрування; м. Харків, Україна; e-mail: v.tretiak@ karazin.ua; Моб. +380(67) 5772733.

Третяк Виктория Павловна - доктор экономических наук, доцент, УНИ «Каразинская школа бизнеса», заведующая кафедрой управления и администрирования, г. Харьков, Украина.

Tretyak Viktoriia - Doctor of Economics, Associate Professor, Karazin Business School, Head of the Department of Management and Administration.

Чупова Дар'я Русланівна - студентка 2-го курсу Магістратури, ННI «Каразінська школа бізнесу», м. Харків, Україна; e-mail: chupova.daria@gmail.com; Моб.+380(66) 8837450.

Чупова Дарья Руслановна - студентка 2-го курса Магистратуры, УНИ «Каразинская школа бизнеса», г. Харьков, Украина.

Chupova Daria - a student of the 2nd year of the Magistracy, Karazin Business School, Kharkiv, Ukraine. 